University of Nebraska - Lincoln

DigitalCommons@University of Nebraska - Lincoln

Faculty Publications: Department of Entomology

Entomology, Department of

2-1-2007

\title{
Influence of Buffalograss Management Practices on Western Chinch Bug and Its Beneficial Arthropods
}

\author{
Jeffrey Carstens \\ University of Nebraska-Lincoln \\ Tiffany Heng-Moss \\ University of Nebraska-Lincoln, thengmoss2@unl.edu \\ Frederick P. Baxendale \\ University of Nebraska-Lincoln, fbaxendale1@unl.edu \\ Roch E. Gaussoin \\ University of Nebraska-Lincoln, rgaussoin1@unl.edu \\ Kevin Frank \\ Michigan State University \\ See next page for additional authors
}

Follow this and additional works at: https://digitalcommons.unl.edu/entomologyfacpub

Part of the Entomology Commons

Carstens, Jeffrey; Heng-Moss, Tiffany; Baxendale, Frederick P.; Gaussoin, Roch E.; Frank, Kevin; and Young, Linda J., "Influence of Buffalograss Management Practices on Western Chinch Bug and Its Beneficial Arthropods" (2007). Faculty Publications: Department of Entomology. 122.

https://digitalcommons.unl.edu/entomologyfacpub/122

This Article is brought to you for free and open access by the Entomology, Department of at DigitalCommons@University of Nebraska - Lincoln. It has been accepted for inclusion in Faculty Publications: Department of Entomology by an authorized administrator of DigitalCommons@University of Nebraska - Lincoln. 


\section{Authors}

Jeffrey Carstens, Tiffany Heng-Moss, Frederick P. Baxendale, Roch E. Gaussoin, Kevin Frank, and Linda J. Young 


\title{
Influence of Buffalograss Management Practices on Western Chinch Bug and Its Beneficial Arthropods
}

\author{
JEFFREY CARSTENS, TIFFANY HENG-MOSS, ${ }^{1}$ FREDERICK BAXENDALE, \\ ROCH GAUSSOIN, ${ }^{2}$ KEVIN FRANK, ${ }^{3}$ AND LINDA YOUNG ${ }^{4}$
}

Department of Entomology, University of Nebraska, Lincoln, NE 68583

J. Econ. Entomol. 100(1): 136-147 (2007)

\begin{abstract}
A 2-yr study was conducted to document the influence of selected buffalograss, Buchloë dactyloides (Nuttall) Engelmann, management practices (three mowing heights and five nitrogen levels) on the seasonal abundance of the western chinch bug, Blissus occiduus Barber (Heteroptera: Lygaeidae), and its beneficial arthropods. Vacuum, pitfall, and sticky traps samples were collected every $14 \mathrm{~d}$ from the middle of May through October from western chinch bug-resistant ('Prestige') and -susceptible ('378') buffalograss management plots. In total, 27,374 and 108,908 western chinch bugs were collected in vacuum and pitfall traps, respectively. More than $78 \%$ of all western chinch bugs were collected from the highly susceptible buffalograss 378 . Significantly more bigeyed bugs (Geocoridae: Geocoris spp.) were collected from the 378 buffalograsss management plots than the Prestige plots. In contrast, buffalograss cultivar had little influence on the abundance of other beneficial arthropods collected. Statistically, western chinch bugs were least abundant at the lowest mowing height $(2.5 \mathrm{~cm})$ and increased in abundance with increasing fertility. Numerically, however, differences among management levels on western chinch bug abundance were minimal. Numerous beneficial arthropods were collected from buffalograss management plots, including spiders, predatory ants, ground beetles (Carabidae), rove beetles (Staphylinidae), bigeyed bugs, and several species of hymenopterous parasitoids. In general, beneficial arthropods were essentially unaffected by either mowing height or nitrogen level. Scelionid wasps represented $66.3 \%$ of the total parasitoids collected. The total number of scelionid wasps collected among the three mowing heights and five nitrogen levels were approximately equal.
\end{abstract}

KEY WORDS buffalograss, beneficial arthropods, western chinch bugs, Blissus occiduus, sampling

For many years, buffalograss has been recommended for low-maintenance turfgrass areas because of its low fertilizer requirement and drought tolerance. Currently, this warm-season grass, which is native to the central Great Plains, is grown in both low management (e.g., roadsides, medians, golf course roughs, low-use sites, nonirrigated areas, and slopes) and high-management (e.g., golf course fairways, and home lawns) areas (Riordan et al. 1998).

The anticipated increase in the use of buffalograss as a turfgrass calls for greater knowledge of known and potential insect pests. Among the arthropods reported as pests of buffalograss are the rhodesgrass mealybug, Antonina graminis (Maskell); the eriophyid mite Eriophytes slykhuisi (Hall); buffalograss webworm, Surattha indentella (Kearfott); the white grub Phyllophaga

\footnotetext{
${ }^{1}$ Corresponding author, e-mail: thengmoss2@unl.edu.

${ }^{2}$ Department of Agronomy and Horticulture, University of Nebraska, Lincoln, NE 68583.

${ }^{3}$ Department of Crop and Soil Sciences, Michigan State University, East Lansing, MI, 48824.

${ }^{4}$ Department of Statistics, University of Florida, Gainesville, FL 32610.
}

crinita (Burmeister); the grass-feeding mealybugs Tridiscus sporoboli (Cockerell) and Trionymus sp.; and the western chinch bug, Blissus occiduus Barber (Baxendale et al. 1994, 1999).

B. occiduus has emerged as one of the most serious insect pests of buffalograss in the central Great Plains (Baxendale et al. 1999). Currently, the reported distribution of B. occiduus includes California, Arizona, Oklahoma, Colorado, Kansas, Montana, Nebraska, and New Mexico in the United States; and Alberta, British Columbia, Manitoba, and Saskatchewan in Canada (Bird and Mitchener 1950, Slater 1964, Baxendale et al. 1999).

B. occiduus has two annual generations. First generation B. occiduus adults are present from June to August, with second generation adults occurring in August and remaining active until the onset of freezing temperatures (Baxendale et al. 1999). Associated with B. occiduus and other buffalograss-inhabiting insects are numerous beneficial arthropods, including bigeyed bugs, spiders, ants, ground beetles, rove beetles, and several species of parasitoid wasps (Heng-Moss et al. 1998).

Numerous researchers (Horn 1962, Kerr 1966, Cockfield and Potter 1985, Kortier Davis and Smitley 
1990, Braman and Pendley 1993, Heng-Moss et al. 1998) have investigated the effects of various turfgrass management regimes on insect populations. Horn (1962), for example, found that the nitrogen level applied to the turfgrass was positively correlated with insect damage, with increased nitrogen resulting in higher densities of the southern chinch bug, Blissus insularis Barber, in St. Augustinegrass. Similarly, Kerr (1966) reported that excessive fertilization encouraged southern chinch bug infestations, possibly by enhancing the nutritional value of the grass. Kortier Davis and Smitley (1990) reported that Kentucky bluegrass thatch thickness was positively correlated with hairy chinch bug, Blissus leucopterus hirtus Montandon, abundance. Cockfield and Potter (1985) showed that numbers of sheet web and dwarf spiders (Linyphiidae) and ground beetles and tiger beetles (Carabidae) were lower in high-maintenance bluegrass than in low-maintenance bluegrass. It is noteworthy, however, that the high-maintenance protocols in this study included both insecticide and fungicide applications.

Braman and Pendley (1993) investigated the effects of fertilizer, herbicides, and insecticide applications on insect populations, and reported minimal effects of management on either the diversity or density of beneficial insects. Likewise, Heng-Moss et al. (1998) reported that beneficial arthropods enemy composition and abundance in buffalograss was not strongly affected by the level of turfgrass maintenance. However, all buffalograss management levels in this study were relatively low.

Additional work is needed to fully understand the effects of turfgrass management practices on the composition and abundance of western chinch bugs and their beneficial arthropods. Accordingly, the objective of this research was to document the influence of selected buffalograss management practices (mowing height and nitrogen level) on the seasonal abundance of B. occiduus and its beneficial arthropods.

\section{Materials and Methods}

A field study was undertaken on the buffalograss '378' and 'Prestige' (previously reported as NE91-118) to document the influence of management practices (mowing height and nitrogen level) on the seasonal abundance of B. occiduus, and its natural enemies. This 2-yr field study used research evaluation plots established by Frank et al. (2004) in 1995 at the John Seaton Anderson Facility, near Mead, NE.

The experimental design was a split-split plot design with three replications for each treatment combination. Each split-split plot measured 1.5 by $3.0 \mathrm{~m}$. The main plot factor, buffalograss selection (378 and Prestige), was in a randomized complete block design. The split plot factor was mowing height $(2.5,5.0$, and 7.5 $\mathrm{cm})$ and was completely randomized within each main plot. The split-split plot factor was nitrogen rate $\left(0,24,49,98\right.$, and $\left.195 \mathrm{~kg} \mathrm{~N} \mathrm{ha}^{-1} \mathrm{yr}^{-1}\right)$ and was completely randomized within each split plot. Prestige and 378 were used in this study because of their differing levels of resistance to western chinch bug. Prestige has been characterized as highly to moderately resistant and 378 as highly susceptible to B. occiduus (HengMoss et al. 2002).

Each spring (2001 and 2002), preemergence and postemergence herbicides were applied to the turf plots. The preemergence herbicide pendimethalin [ $\mathrm{N}$-(1-ethylpropyl)-3,4-dimethyl-2,6-dinitrobenzenamine] was applied at 1.58 liters active ingredient (AI) $\mathrm{ha}^{-1}$ as split applications. One postemergence application of triclopyr [3,5,6-trichloro-2-pyridinyloxyacetic acid, triethylamine salt $]$ at $390 \mathrm{ml}$ (AI) $\mathrm{ha}^{-1}$ and clopyralid [3,6dichloro-2-pyridine carboxylic acid, triethylamine salt] at $143 \mathrm{ml}$ (AI) ha ${ }^{-1}$ also was applied each year. In addition, glyphosate, $\mathrm{N}$-(phosphonomethyl) glycine, ammonium salt at $2.8 \mathrm{~kg}$ (AI) ha ${ }^{-1}$ was used to spot-treat escaped weeds by using a brush applicator to reduce herbicide contact with buffalograss.

Beginning at the onset of active growth (May), plots were mowed weekly (clippings removed) at the specified height by using a walk-behind, rotary John Deere model \#14SB mower. Nitrogen fertilizer (poly S coated with an analysis of 36-3-6, N-P-K) was applied using a drop spreader as specified in the experimental protocol with two equal applications in June and again in July to reach the total annual amount of nitrogen. Plots were irrigated with $1.3 \mathrm{~cm}$ of water immediately after fertilizer applications, and every $2 \mathrm{wk}$ with $5.0 \mathrm{~cm}$ of water during the peak growing season for buffalograss (June through August).

To assess the influence of buffalograss management practices on B. occiduus and its natural enemies, three collection methods were used: vacuum samples, pitfall traps, and yellow sticky traps. During both years of the study, samples were taken approximately every $14 \mathrm{~d}$ from mid-May until only low numbers of insects were collected on two consecutive sampling dates in the fall, or after the first hard freeze. These samples served to monitor the abundance and seasonal occurrence of selected arthropods and their beneficial arthropods. Specific sampling dates for 2001 and 2002 are listed in Table 1.

Vacuum Samples. This technique provided a "snap shot" of the arthropods present at the specific time of sampling. A BioQuip (Gardena, CA), DC hand-held insect vacuum (model \#2820B) connected to a $12-\mathrm{V}$ battery was used to extract arthropods from the soil surface. Vacuum samples were placed in Berlese funnels maintained at $32^{\circ} \mathrm{C}$ for $24 \mathrm{~h}$. Collected arthropods were preserved in covered 104-ml Solo cups with 75\% ethyl alcohol until counted. Two vacuum samples (15.88 $\mathrm{cm}$ in diameter, $0.04 \mathrm{~m}^{2}$ total area per plot) were collected from randomly selected locations in each plot for a total of 180 samples per collection date. Insect pests and beneficial arthropods were collected and grouped into the following taxa: western chinch bugs (B. occiduus) and beneficial arthropods: ground beetles (Carabidae), rove beetles (Staphylinidae), ants (Formicidae), bigeyed bugs (Geocoris spp.: Geocoridae); and spiders: wolf spiders (Lycosidae), sheetweb and dwarf spiders (Linyphiidae), jumping spiders (Salticidae), and crab spiders (Thomisidae). 
Table 1. Collection dates for vacuum samples, pitfall traps, and sticky traps

\begin{tabular}{|c|c|c|c|c|c|c|c|c|c|c|c|}
\hline \multirow{2}{*}{ Yr } & \multicolumn{11}{|c|}{ Collection dates for vacuum samples } \\
\hline & 1 & 2 & 3 & 4 & 5 & 6 & 7 & 8 & 9 & 10 & 11 \\
\hline 2001 & 22 May & 8 June & 23 June & 5 July & 18 July & 1 Aug. & 16 Aug. & 29 Aug. & 14 Sept. & 28 Sept. & 12 Oct. \\
\hline 2002 & 15 May & 29 May & 12 June & 25 June & 11 July & 24 July & 8 Aug. & 20 Aug. & 6 Sept. & 20 Sept. & 1 Oct. \\
\hline \multicolumn{12}{|c|}{ Collection dates of pitfall and sticky traps } \\
\hline 2001 & 29 May & 12 June & 26 June & 12 July & 25 July & 9 Aug. & 21 Aug. & 5 Sept. & 21 Sept. & 1 Oct. & 19 Oct. \\
\hline 2002 & 22 May & 4 June & 18 June & 2 July & 17 July & 31 July & 14 Aug. & 29 Aug. & 10 Sept. & 24 Sept. & 8 Oct. \\
\hline
\end{tabular}

These taxa were selected because they are commonly found in buffalograss turf (Heng-Moss et al. 1998).

Pitfall Traps. The seasonal abundance of surfaceinhabiting insects (including B. occiduus and beneficial arthropods) was sampled with pitfall traps. Each pitfall trap was constructed using a 474-ml Solo cup, a 207-ml funnel Solo cup, and a 104-ml Solo cup (Morrill 1975). A golf cup cutter was used to install pitfall traps into the turf with rims level with soil surface. Standard automobile antifreeze (ethylene glycol) was used as a killing solution. Samples were collected every $14 \mathrm{~d}$ and stored in $75 \%$ ethyl alcohol until counted. Two pitfall traps $(10.6 \mathrm{~cm}$ in diameter each, $0.0186 \mathrm{~m}^{2}$ total area per plot) were oriented longitudinally with the long axis of each plot into a row $\approx 0.3 \mathrm{~m}$ on either side of the middle in each plot for a total of 180 samples per collection date. The same taxa recorded from vacuum samples were recorded in pitfall traps.

Sticky Traps. The seasonal abundance of parasitoids was monitored using Pherocon AM sticky traps with grids manufactured by Trécé Incorporated (Adair, OK). Yellow sticky trap rectangles measuring 11 by 18 $\mathrm{cm}$ were rolled into a cylinder and stapled to a $30-\mathrm{cm}$ wooden garden stake. One trap was placed in the

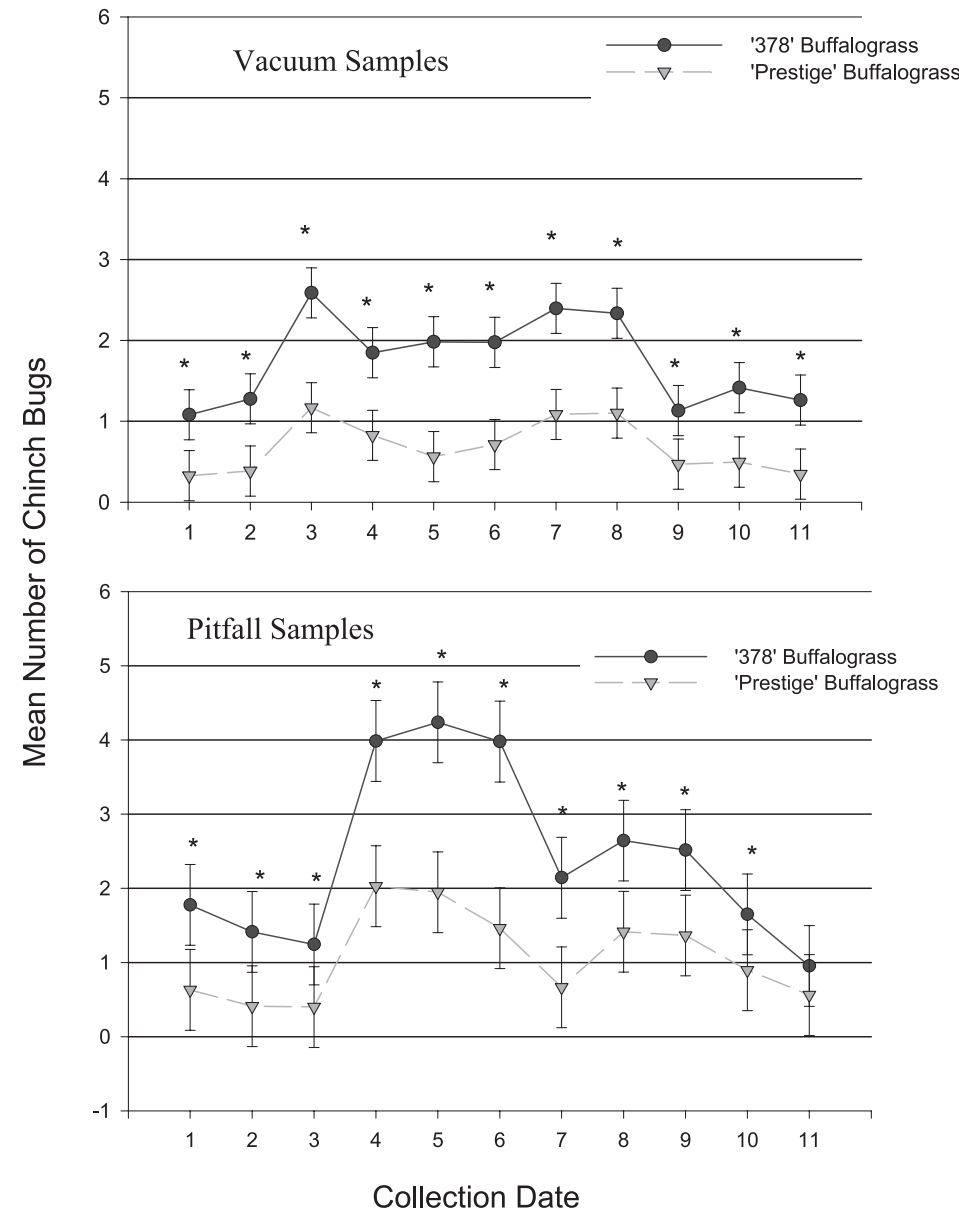

Fig. 1. Mean number of western chinch bugs collected in vacuum and pitfall trap samples from two buffalograss cultivars. *, significantly different at $P \leq 0.05$. 
middle of each plot for a total of 90 samples per collection date. Traps were changed every $2 \mathrm{wk}$ and the following parasitic Hymenoptera were recorded: fairyflies (Mymaridae), scelionid wasps (Scelionidae), trichogrammatid wasps (Trichogrammatidae), aphelinid wasps (Aphelinidae), and braconid wasps (Braconidae).

Statistical Analyses. Data were analyzed using mixed model analysis (PROC MIXED, SAS Institute 1999) to detect differences in the abundance of $B$. occiduus and its beneficial arthropods among management practices. When appropriate, means were separated using Fisher least significant difference (LSD) procedure. Effects with $P$ values less than or equal to 0.05 were considered significant.

Mixed model analysis detected no significant differences in the number of western chinch bugs and other beneficial arthropod groups between sampling years, and there was no interaction between sampling years and any other factor. Therefore, the averages over 2001 and 2002 are reported here.

\section{Results and Discussion}

\section{Western Chinch Bugs}

Vacuum samples and pitfall traps reflected the effects of buffalograss selection, mowing height, and nitrogen level on western chinch bug abundance. In total, 27,374 and 108,908 western chinch bugs were collected in vacuum samples and pitfall traps, respectively.

Buffalograss Cultivar Effects. Vacuum Samples. There was a significant interaction between buffalograss cultivars and collection dates $(F=6.06$; $\mathrm{df}=$ $10,1,500 ; P<0.0001)$. However, the general pattern of western chinch bug abundance (Fig. 1) was similar for the two buffalograss selections. Significant differences in the mean number of western chinch bugs were observed on all collection dates with more western chinch bugs consistently collected in buffalograss 378 (Fig. 1). Seventy-eight percent of all western chinch bugs were collected from the highly susceptible buffalograss 378.

Pitfall Traps. There was a significant interaction between buffalograss cultivars and collection dates $(F=29.33 ; \mathrm{df}=10,1,500 ; P<0.0001)$. Again, the general pattern of western chinch bug abundance (Fig. 1) was similar for the two buffalograss cultivars, with more western chinch bugs in 378 buffalograss than in Prestige. Significant differences in the mean number of western chinch bugs were detected on all collection dates, except collection date 11 (Fig. 1). As with the vacuum samples, more western chinch bugs $(86.3 \%)$ were collected from buffalograss 378 , supporting prior reports that 378 is highly susceptible.

These results concur with the findings of HengMoss et al. (2002) who reported that 378 is highly susceptible to B. occiduus, whereas Prestige is highly to moderately resistant. Heng-Moss et al. (2003) later reported that Prestige exhibits both antixenosis and tolerance resistant mechanisms, which may
Table 2. Mean number of western chinch bugs collected in vacuum and pitfall samples from three mowing heights

\begin{tabular}{|c|c|c|c|c|c|c|}
\hline \multirow{3}{*}{$\begin{array}{l}\text { Sampling } \\
\text { date }\end{array}$} & \multicolumn{6}{|c|}{ Mowing ht } \\
\hline & \multicolumn{2}{|c|}{$2.5 \mathrm{~cm}$} & \multicolumn{2}{|c|}{$5.0 \mathrm{~cm}$} & \multicolumn{2}{|c|}{$7.5 \mathrm{~cm}$} \\
\hline & Vacuum $^{a}$ & Pitfall $^{b}$ & Vacuum $^{a}$ & Pitfall $^{b}$ & Vacuum $^{a}$ & Pitfall $^{b}$ \\
\hline 1 & $0.6 \mathrm{a}$ & $1.0 \mathrm{a}$ & $1.0 \mathrm{~b}$ & $1.4 \mathrm{~b}$ & $0.6 \mathrm{a}$ & $1.2 \mathrm{ab}$ \\
\hline 2 & $0.5 \mathrm{a}$ & $0.9 \mathrm{a}$ & $1.2 \mathrm{~b}$ & $1.0 \mathrm{a}$ & $0.8 \mathrm{a}$ & $0.8 \mathrm{a}$ \\
\hline 3 & $1.4 \mathrm{a}$ & $0.5 \mathrm{a}$ & $2.3 \mathrm{c}$ & $0.9 \mathrm{~b}$ & $1.9 \mathrm{~b}$ & $1.0 \mathrm{~b}$ \\
\hline 4 & $0.9 \mathrm{a}$ & $2.6 \mathrm{a}$ & $1.6 \mathrm{~b}$ & $3.4 \mathrm{~b}$ & $1.5 \mathrm{~b}$ & $3.0 \mathrm{~b}$ \\
\hline 5 & $0.8 \mathrm{a}$ & $2.6 \mathrm{a}$ & $1.5 \mathrm{~b}$ & $3.5 \mathrm{~b}$ & $1.4 \mathrm{~b}$ & $3.2 \mathrm{~b}$ \\
\hline 6 & $1.0 \mathrm{a}$ & $2.4 \mathrm{a}$ & $1.6 \mathrm{~b}$ & $3.0 \mathrm{~b}$ & $1.4 \mathrm{~b}$ & $2.7 \mathrm{ab}$ \\
\hline 7 & $1.3 \mathrm{a}$ & $1.3 \mathrm{a}$ & $2.0 \mathrm{~b}$ & $1.5 \mathrm{a}$ & $1.9 \mathrm{~b}$ & $1.4 \mathrm{a}$ \\
\hline 8 & $1.4 \mathrm{a}$ & $1.7 \mathrm{a}$ & $1.9 \mathrm{~b}$ & $2.1 \mathrm{~b}$ & $1.9 \mathrm{~b}$ & $2.2 \mathrm{~b}$ \\
\hline 9 & $0.6 \mathrm{a}$ & $1.6 \mathrm{a}$ & $0.9 \mathrm{~b}$ & $2.0 \mathrm{~b}$ & $0.9 \mathrm{~b}$ & $2.2 \mathrm{~b}$ \\
\hline 10 & $0.7 \mathrm{a}$ & $1.0 \mathrm{a}$ & $1.1 \mathrm{~b}$ & $1.3 \mathrm{ab}$ & $1.1 b$ & $1.6 \mathrm{~b}$ \\
\hline 11 & $0.6 \mathrm{a}$ & $0.5 \mathrm{a}$ & $1.0 \mathrm{a}$ & $0.8 \mathrm{a}$ & $0.8 \mathrm{a}$ & $0.9 \mathrm{a}$ \\
\hline
\end{tabular}

Means within the same sampling date and sampling method (vacuum or pitfall) followed by the same letter are not significantly different $(P>0.05)$.

${ }^{a}$ Standard error vacuum samples $=0.3$.

${ }^{b}$ Standard error pitfall traps $=0.5$.

help explain why $B$. occiduus was consistently less abundant in this western chinch bug-resistant buffalograss.

Mowing Height Effects. Vacuum Samples. There was a significant interaction between collection dates and mowing height treatments $(F=1.72$; df $=20$, $1,500 ; P<0.0247)$. Although the general pattern of western chinch bug abundance was similar for the three mowing heights (Table 2), western chinch bug abundance at the $2.5-\mathrm{cm}$ mowing height decreased on collection date 2 , whereas B. occiduus abundance increased in both the 5.0- and 7.5-cm mowing heights. In addition, differences among the three mowing heights were more pronounced on collection date three than any other collection date.

Significant differences in the number of western chinch bugs collected were observed on all dates for the three mowing heights, except collection date 11 (Table 2). More western chinch bugs were consistently collected at the higher mowing heights ( 5.0 and $7.5 \mathrm{~cm})$ than at the lowest mowing height $(2.5 \mathrm{~cm})$. The total number of western chinch bugs collected at the 2.5-, 5.0-, and 7.5-cm mowing heights were 5,841, 11,116 , and 10,417 , respectively.

Pitfall Traps. There was a significant interaction between collection dates and mowing height treatments $(F=2.64 ; \mathrm{df}=20,1,500 ; P<0.0001)$. Again, a general pattern of western chinch bug abundance was similar for the three mowing heights (Table 2). Western chinch bug numbers among the three mowing heights were higher on collection dates 4 and 5, compared with the other nine collection dates. In addition, there was a decrease in western chinch bug abundance in mowing heights 2.5 and $5.0 \mathrm{~cm}$ on collection date 3 , whereas at the same time an increase occurred in western chinch bug numbers at the $7.5-\mathrm{cm}$ mowing height.

Significant differences in the mean number of western chinch bugs between at least two mowing heights were detected on all dates, except on collection dates 


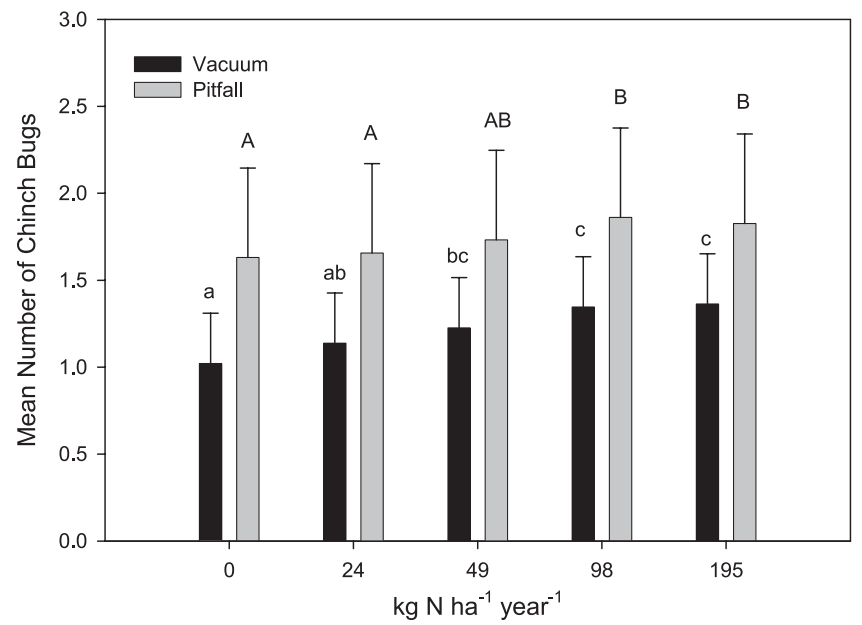

Fig. 2. Mean number of western chinch bugs collected in vacuum and pitfall trap samples from five nitrogen levels. Bars with the same letter (lowercase, vacuum; uppercase, pitfall trap) are not significantly different at $P>0.05$.

2, 7, and 11 (Table 2). Numerically, more western chinch bugs were collected at the higher mowing heights $(5.0$ and $7.5 \mathrm{~cm})$ than at the lower $2.5 \mathrm{~cm}$ mowing height (Table 2). The total number of western chinch bugs collected in pitfall traps at the 2.5-, 5.0 -, and 7.5-cm mowing heights were 32,056, 41,952, and 34,900 , respectively. These results were similar to the vacuum sample data, where the greatest mean number of western chinch bugs was collected at the 5.0-cm mowing height.

Although these studies suggest that western chinch bugs are more abundant at higher mowing heights, the underlying reasons for this phenomenon remain unclear. Beard (1973) noted that bare soil or low mowing heights have greater temperature extremes than higher mowing height turf. Therefore, it may be that western chinch bugs prefer higher mowing height turf because of more favorable environmental conditions.

Beard (1973) also states that higher mowing heights contribute to thatch buildup. Kortier Davis and Smitley (1990) reported that thatch thickness was positively correlated to hairy chinch bug abundance, and Baxendale (1997) suggested that B. occiduus seems to prefer buffalograss stands high in organic debris. These observations support the hypothesis that higher mowed buffalograss with greater amounts of organic debris have increased attractiveness and suitability to B. occiduus.

Nitrogen Effects. Vacuum Samples. Significant differences in the mean number of western chinch bugs were observed among nitrogen levels $(F=5.59$; $\mathrm{df}=$ $4,120 ; P<0.0004)$. As the nitrogen level increased, there was a gradual increase in the number of western chinch bugs collected, with the highest numbers collected at 98 and $195 \mathrm{~kg} \mathrm{~N} \mathrm{ha}^{-1}$ (Fig. 2).

Pitfall Traps. Significant differences in the mean number of western chinch bugs were observed among nitrogen levels $(F=3.60 ; \mathrm{df}=4,120 ; P<0.0082)$. Again, more western chinch bugs were collected from plots with higher nitrogen rates, but the greatest total number of western chinch bugs $(24,153)$ was actually collected at $98 \mathrm{~kg} \mathrm{~N} \mathrm{ha}^{-1}$ (Fig. 2).

Busey and Snyder (1993) reported that higher nitrogen levels enhance western chinch bug activity by increasing the insect's reproduction and survival. These results, along with those from the vacuum samples, also indicate that buffalograss plots maintained at higher nitrogen levels contain larger numbers of western chinch bugs.

\section{Beneficial Arthropods}

Numerous beneficial arthropod taxa were collected from buffalograss plots, including ants, ground beetles, rove beetles, and bigeyed bugs, and several species of spiders (Araneae). Ants and spiders were the most abundant beneficial arthropods collected in both vacuum samples and pitfall traps (Table 3). Pitfall traps collected larger numbers of all beneficial arthropods than vacuum samples. These results are in concurrence with the findings of Heng-Moss et al. (1998).

\section{Bigeyed Bugs}

Vacuum sampling was not an effective method for collecting bigeyed bugs, probably because these insects are relatively fast moving and avoided capture (Borror et al. 1989). In total, only 643 big-eyed bugs were collected in vacuum samples, so these data were not included in analyses.

Table 3. Relative abundance of beneficial arthropods collected in vacuum samples and pitfall traps

\begin{tabular}{lcr}
\hline \hline Arthropod order & Vacuum samples & Pitfall traps \\
\hline Formicidae & 7,742 & 208,862 \\
Araneae & 856 & 25,647 \\
Carabidae & 243 & 5,290 \\
Staphylinidae & 389 & 3,101 \\
Geocoridae & 643 & 2,498 \\
\hline
\end{tabular}


Table 4. Mean number of bigeyed bugs collected in pitfall traps from two buffalograss cultivars, at three mowing heights, and over 11 collection dates

\begin{tabular}{|c|c|c|c|c|c|c|}
\hline \multirow{3}{*}{$\begin{array}{l}\text { Sampling } \\
\text { date }\end{array}$} & \multicolumn{6}{|c|}{ Mowing ht } \\
\hline & \multicolumn{2}{|c|}{$2.5 \mathrm{~cm}^{a}$} & \multicolumn{2}{|c|}{$5.0 \mathrm{~cm}^{a}$} & \multicolumn{2}{|c|}{$7.5 \mathrm{~cm}^{a}$} \\
\hline & Prestige & 378 & Prestige & 378 & Prestige & 378 \\
\hline 1 & $0.1 \mathrm{aA}$ & $0.2 \mathrm{aA}$ & $0.1 \mathrm{aA}$ & $0.1 \mathrm{aA}$ & $0.1 \mathrm{aA}$ & $0.1 \mathrm{aA}$ \\
\hline 2 & $0.2 \mathrm{aA}$ & $0.3 \mathrm{aA}$ & $0.2 \mathrm{aA}$ & $0.3 \mathrm{aA}$ & $0.1 \mathrm{aA}$ & $0.2 \mathrm{aA}$ \\
\hline 3 & $0.2 \mathrm{aA}$ & $0.4 \mathrm{aA}$ & $0.2 \mathrm{aA}$ & $0.2 \mathrm{aA}$ & $0.1 \mathrm{aA}$ & $0.2 \mathrm{aA}$ \\
\hline 4 & $0.4 \mathrm{aA}$ & $0.6 \mathrm{bA}$ & $0.3 \mathrm{aAB}$ & $0.1 \mathrm{aB}$ & $0.2 \mathrm{aB}$ & $0.3 \mathrm{aB}$ \\
\hline 5 & $0.7 \mathrm{aA}$ & $0.9 \mathrm{bA}$ & $0.5 \mathrm{aB}$ & $0.6 \mathrm{aB}$ & $0.3 \mathrm{aB}$ & $0.4 \mathrm{aC}$ \\
\hline 6 & $0.4 \mathrm{aA}$ & $1.4 \mathrm{bA}$ & $0.5 \mathrm{aA}$ & $0.8 \mathrm{bB}$ & $0.3 \mathrm{aA}$ & $0.4 \mathrm{aC}$ \\
\hline 7 & $0.1 \mathrm{aA}$ & $0.7 \mathrm{bA}$ & $0.2 \mathrm{aA}$ & $0.3 \mathrm{aB}$ & $0.1 \mathrm{aA}$ & $0.3 \mathrm{aB}$ \\
\hline 8 & $0.4 \mathrm{aAB}$ & $0.8 \mathrm{bA}$ & $0.4 \mathrm{aB}$ & $0.5 \mathrm{aB}$ & $0.2 \mathrm{aA}$ & $0.4 \mathrm{bB}$ \\
\hline 9 & $0.1 \mathrm{aA}$ & $0.4 \mathrm{bA}$ & $0.1 \mathrm{aA}$ & $0.2 \mathrm{aA}$ & $0.2 \mathrm{aA}$ & $0.3 \mathrm{aA}$ \\
\hline 10 & $0.1 \mathrm{aA}$ & $0.3 \mathrm{bA}$ & $0.2 \mathrm{aA}$ & $0.2 \mathrm{aA}$ & $0.1 \mathrm{aA}$ & $0.3 \mathrm{aA}$ \\
\hline 11 & $0.0 \mathrm{aA}$ & $0.2 \mathrm{bA}$ & $0.1 \mathrm{aA}$ & $0.1 \mathrm{aA}$ & $0.1 \mathrm{aA}$ & $0.3 \mathrm{aA}$ \\
\hline
\end{tabular}

Means within the same sampling date (row) and in the same mowing height followed by the same lowercase letter are not significantly different $(P>0.05)$. Means within the same sampling date (row) and in the same buffalograss cultivar followed by the same uppercase letter are not significantly different $(P>0.05)$.

${ }^{a}$ Standard error $=0.1$.

Buffalograss Cultivar Effects. Pitfall Traps. There was a significant interaction among buffalograss cultivars, collection dates, and mowing height treatments $(F=2.17 ; \mathrm{df}=20,1,498 ; P<0.0020)$. Although the general pattern of bigeyed bug abundance was the same for both buffalograss cultivars (Table 4), the mean number of bigeyed bugs peaked on collection date 5 and 6 for Prestige and 378, respectively. In addition, the effect of mowing height was more pronounced for 378 , especially at the $2.5-\mathrm{cm}$ mowing height. These factors led to a significant three-way interaction among buffalograss cultivars, mowing height, and collection date.

The mean number of bigeyed bugs collected from 378 was significantly higher than the mean number collected from Prestige on collection dates 4, 5, 6, 7, 8,
9 , and 10 at the 2.5-cm mowing height (Table 4). Big-eyed bug abundance was also significantly higher in 378 than Prestige on collection date 6 and also 8, 10, and 11 at the 5.0- and 7.5-cm mowing height, respectively. In total, 834 and 1,664 bigeyed bugs were collected in Prestige and 378, respectively. Greater numbers of bigeyed bugs collected in 378 may reflect the higher number of western chinch bugs present in the same buffalograss cultivars. These data suggest that planting resistant buffalograss cultivars may help reduce the potential for western chinch bug infestations, without adversely affecting the abundance of this common turfgrass predator.

Mowing Height Effects. Pitfall Traps. The mean number of big-eyed bugs collected from the $2.5-\mathrm{cm}$ mowing height was significantly greater than the mean number of bigeyed bugs collected at the $7.5-\mathrm{cm}$ mowing height for 378 and Prestige on collection dates 4, $5,6,7$, and 8 and on dates 4 and 5 , respectively (Table 4). In addition, significantly more bigeyed bugs were collected in Prestige at the $5.0-\mathrm{cm}$ mowing height than at the $7.5 \mathrm{~cm}$ mowing height on collection date eight (Table 4). In contrast, western chinch bugs were more abundant at higher mowing heights. This suggests that lower mowing heights (e.g., $2.5 \mathrm{~cm}$ ) may suppress western chinch bug numbers, whereas slightly increasing the abundance of big-eyed bugs. In total, $1,153,813$, and 532 bigeyed bugs were collected at the 2.5-, 5.0-, and 7.5-cm mowing heights, respectively.

Nitrogen Effects. Pitfall Traps. There was no significant interaction between nitrogen and any other factor (i.e., buffalograss selection, mowing height, and collection date), but the main effect of nitrogen was significant $(F=3.07 ; \mathrm{df}=4,120 ; P<0.0189)$. As nitrogen level increased, the mean number of bigeyed bugs also increased (Fig. 3). It is possible that the increased numbers of bigeyed bugs may correlate with the larger numbers of western chinch bugs collected at higher nitrogen levels.

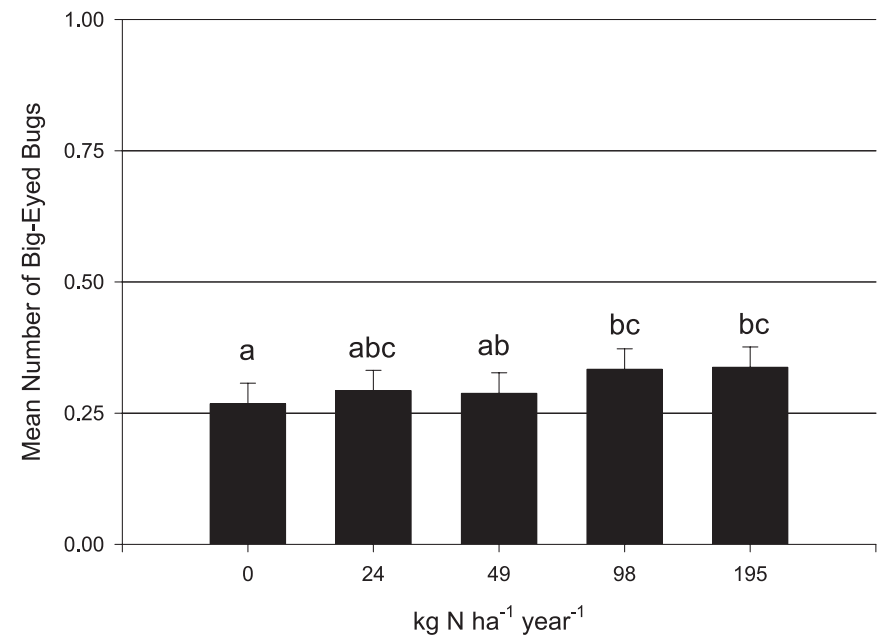

Fig. 3. Mean number of bigeyed bugs collected in pitfall traps from five nitrogen levels. Bars with the same letter are not significantly different at $P>0.05$. 
Table 5. Mean number of ground beetles collected in pitfall traps from two buffalograss cultivars among three mowing heights and five nitrogen levels

\begin{tabular}{|c|c|c|c|c|c|c|}
\hline \multirow{3}{*}{$\begin{array}{c}\text { Nitrogen } \\
\text { level }^{a}\end{array}$} & \multicolumn{6}{|c|}{ Mowing ht } \\
\hline & \multicolumn{2}{|c|}{$2.5 \mathrm{~cm}^{b}$} & \multicolumn{2}{|c|}{$5.0 \mathrm{~cm}^{b}$} & \multicolumn{2}{|c|}{$7.5 \mathrm{~cm}^{b}$} \\
\hline & Prestige & 378 & Prestige & 378 & Prestige & 378 \\
\hline 0 & $0.59 \mathrm{aAB}$ & $0.72 \mathrm{aA}$ & $0.65 \mathrm{aB}$ & $0.66 \mathrm{aAB}$ & $0.45 \mathrm{aA}$ & $0.55 \mathrm{aB}$ \\
\hline 24 & $0.58 \mathrm{aA}$ & $0.68 \mathrm{aA}$ & $0.48 \mathrm{aAB}$ & $0.82 \mathrm{aA}$ & $0.41 \mathrm{aB}$ & $0.52 \mathrm{aB}$ \\
\hline 49 & $0.67 \mathrm{aA}$ & $0.66 \mathrm{aA}$ & $0.52 \mathrm{aA}$ & $0.79 \mathrm{bA}$ & $0.51 \mathrm{aB}$ & $0.75 \mathrm{bA}$ \\
\hline 98 & $0.74 \mathrm{aA}$ & $0.63 \mathrm{aA}$ & $0.49 \mathrm{aB}$ & $0.82 \mathrm{bB}$ & $0.48 \mathrm{aB}$ & $0.69 \mathrm{bAB}$ \\
\hline 195 & $0.65 \mathrm{aA}$ & $0.73 \mathrm{aA}$ & $0.54 \mathrm{aA}$ & $0.77 \mathrm{bA}$ & $0.58 \mathrm{aA}$ & $0.78 \mathrm{bA}$ \\
\hline
\end{tabular}

Means within the same nitrogen level (row) and in the same mowing height followed by the same lowercase letter are not significantly different $(P>0.05)$. Means within the same nitrogen level (row) and the same buffalograss cultivar followed by the same uppercase letter are not significantly different $(P>0.05)$.

${ }^{a} \mathrm{~kg} \mathrm{~N} \mathrm{ha}^{-1} \mathrm{yr}^{-1}$

${ }^{b}$ Standard error $=0.1$

\section{Ground Beetles}

Daytime vacuum sampling is not an effective method for collecting ground beetles as these insects are largely nocturnal (Borror et al. 1989). In total, only 243 ground beetles were collected with vacuum samples, so these data were not included in analyses.

Buffalograss Cultivar Effects. Pitfall Traps. There was a significant interaction among buffalograss cultivars, mowing height and nitrogen treatments $(F=$ 2.51 ; $\mathrm{df}=8,120 ; P<0.0149)$. The mean number of ground beetles in 378 at the $2.5-\mathrm{cm}$ mowing height decreased from 0 through $98 \mathrm{~kg} \mathrm{~N} \mathrm{ha}{ }^{-1}$ and then increased from 98 to $195 \mathrm{~kg} \mathrm{~N} \mathrm{ha}{ }^{-1}$ (Table 5). In contrast, the mean number of ground beetles in Prestige plots at the $2.5-\mathrm{cm}$ mowing height slightly increased as nitrogen increased, except at $195 \mathrm{~kg} \mathrm{~N} \mathrm{ha}^{-1}$. Significant differences in the mean number of ground beetles between the two buffalograss cultivars and among three mowing heights and five nitrogen levels were observed (Table 5): 378 buffalograss had significantly more ground beetles than Prestige at the 5.0and 7.5-cm mowing heights at the 49,98, and $195 \mathrm{~kg} \mathrm{~N}$ $\mathrm{ha}^{-1}$ (Table 5). At the $2.5-\mathrm{cm}$ mowing height, there were no differences in ground beetle abundance between the two buffalograss cultivars.

Mowing Height and Nitrogen Effects. Pitfall Traps. Significant differences in the mean number of ground beetles among the three mowing heights were observed in 378 at 0,24 , and $98 \mathrm{~kg} \mathrm{~N} \mathrm{ha}^{-1}$ but not at 49 and $195 \mathrm{~kg} \mathrm{~N} \mathrm{ha}^{-1}$ (Table 5). Significant differences in the mean number of ground beetles among three mowing heights were observed in Prestige at 0, 24, 49, and $98 \mathrm{~kg} \mathrm{~N} \mathrm{ha}^{-1}$ but not at $195 \mathrm{~kg} \mathrm{~N} \mathrm{ha}^{-1}$ (Table 5).

\section{Rove Beetles}

Vacuum samples and pitfall traps collected 389 and 3,101 rove beetles, respectively. Due to the low numbers of rove beetles in vacuum samples, only pitfall data were included in analyses.

Buffalograss Cultivar Effects. Pitfall Traps. There was a significant interaction between buffalograss cultivars and collection dates $(F=8.57 ; \mathrm{df}=10,1,468 ; P<$ $0.0001)$. A large increase in the abundance of rove beetles in 378 occurred on collection date 2 (Fig. 4). In addition, a slight decrease in the number of rove beetles in Prestige occurred on collection date 6, whereas an increase in rove beetles in 378 occurred on the same collection date. These factors probably explain the significant interaction between buffalograss and collection date. Significant differences in the mean number of rove beetles from 378 and Prestige were observed on collection dates 2, 10, and 11 (Fig.

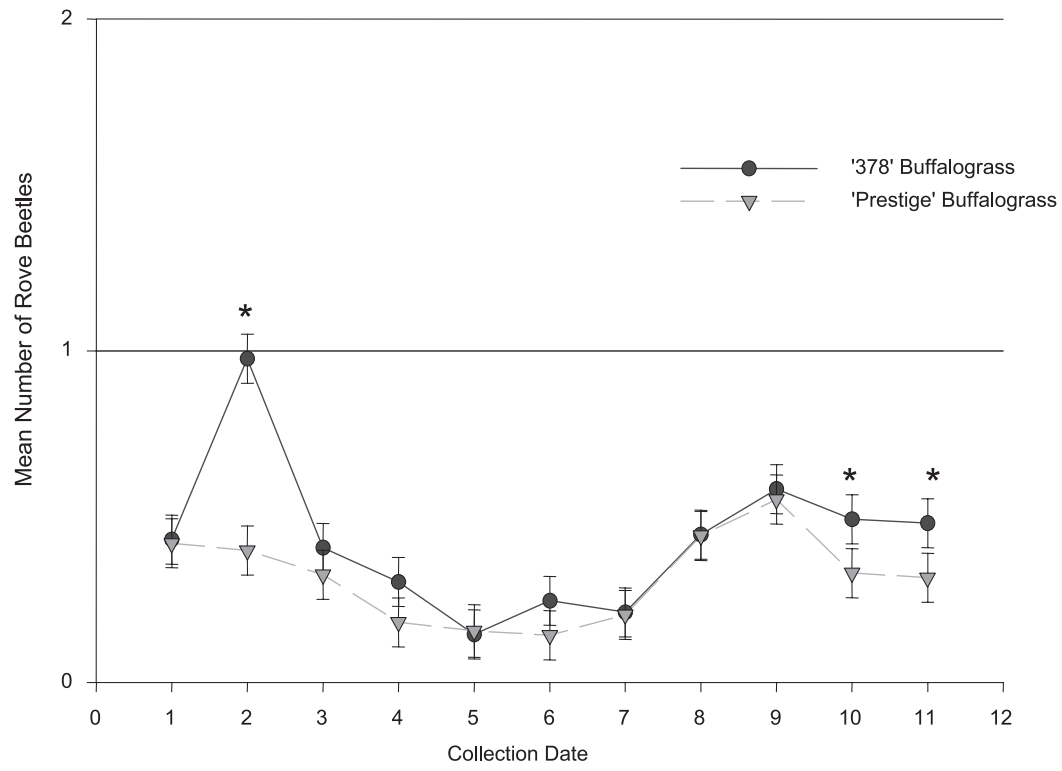

Fig. 4. Mean number of rove beetles collected in pitfall traps from two buffalograss cultivars. *, significantly different at $P \leq 0.05$. 
Table 6. Mean number of rove beetles collected in pitfall traps from three mowing heights among five nitrogen levels

\begin{tabular}{|c|c|c|c|}
\hline \multirow{2}{*}{$\begin{array}{l}\text { Nitrogen } \\
\text { level }^{a}\end{array}$} & \multicolumn{3}{|c|}{ Mowing ht } \\
\hline & $2.5 \mathrm{~cm}^{b}$ & $5.0 \mathrm{~cm}^{b}$ & $7.5 \mathrm{~cm}^{b}$ \\
\hline 0 & $0.29 \mathrm{aA}$ & $0.35 \mathrm{aA}$ & $0.30 \mathrm{aA}$ \\
\hline 24 & $0.34 \mathrm{aAB}$ & $0.38 \mathrm{aA}$ & $0.41 \mathrm{aB}$ \\
\hline 49 & $0.45 \mathrm{aC}$ & $0.37 \mathrm{aA}$ & $0.36 \mathrm{aA}$ \\
\hline 98 & $0.36 \mathrm{aABC}$ & $0.42 \mathrm{aA}$ & $0.34 \mathrm{aA}$ \\
\hline 195 & $0.39 \mathrm{aBC}$ & $0.35 \mathrm{aA}$ & $0.47 \mathrm{aB}$ \\
\hline
\end{tabular}

Means within the same nitrogen level (row) followed by the same lowercase letter are not significantly different $(P>0.05)$. Means within the same mowing height (column) followed by the same uppercase letter are not significantly different $(P>0.05)$.

${ }^{a} \mathrm{~kg} \mathrm{~N} \mathrm{ha}^{-1}$ year $^{-1}$.

${ }^{b}$ Standard error $=0.1$

4). The mean numbers of rove beetles collected in 378 and Prestige followed a similar trend on the remaining collection dates.

Mowing Height and Nitrogen Effects. Pitfall Traps. There was a significant interaction between mowing height and nitrogen treatments $(F=2.19$; df $=8,120$; $P<0.0331)$. The mean number of rove beetles collected from the three mowing heights at the five nitrogen levels was highly variable (Table 6). The mean number of rove beetles at the lowest mowing height $(2.5 \mathrm{~cm})$ increased at $49 \mathrm{~kg} \mathrm{~N} \mathrm{ha}^{-1}$, whereas at the same nitrogen level there was a decrease in the mean number of rove beetles at the highest mowing heights. In addition, there was a decrease in the mean number of rove beetles at the $5.0-\mathrm{cm}$ mowing height at $195 \mathrm{~kg}$ $\mathrm{N} \mathrm{ha}{ }^{-1}$, whereas at the same nitrogen level, an increase in the mean number of rove beetles occurred in both the 2.5- and 7.5-cm cuts.

Significant differences in the mean number of rove beetles from the five nitrogen levels were detected at the lowest and highest heights (Table 6). However, rove beetles were not consistently more abundant at either low or high nitrogen levels.

\section{Spiders}

Vacuum samples and pitfall traps collected a total of 856 and 25,647 spiders, respectively. Due to the low numbers of spiders in vacuum samples, these data were not included in analyses. The limited numbers of spiders collected in vacuum samples is likely related to their sedentary lifestyle and rapid avoidance response to disturbance during sampling.

The most abundant families of spiders collected in pitfall traps during the $2 \mathrm{yr}$ sampled were Lycosidae (9,920), Linyphiidae (4,664), Thomisidae (3,544), and Salticidae $(2,678)$. These results support the conclusions of Vittum et al. (1999) and Potter (1998) who indicated these families are the most abundant in turfgrass. Visual observations during field sampling noted Linyphiidae and Salticidae occasionally consuming $B$. occiduus. All spider families were analyzed and reported as a single taxon.

Buffalograss Cultivar Effects. Pitfall Traps. There was a significant interaction among buffalograss cul-
Table 7. Mean number of spiders collected in pitfall traps from two buffalograss cultivars among three mowing heights and five nitrogen levels

\begin{tabular}{|c|c|c|c|c|c|c|}
\hline \multirow{3}{*}{$\begin{array}{l}\text { Nitrogen } \\
\text { level }^{a}\end{array}$} & \multicolumn{6}{|c|}{ Mowing ht } \\
\hline & \multicolumn{2}{|c|}{$2.5 \mathrm{~cm}^{b}$} & \multicolumn{2}{|c|}{$5.0 \mathrm{~cm}^{b}$} & \multicolumn{2}{|c|}{$7.5 \mathrm{~cm}^{b}$} \\
\hline & Prestige & 378 & Prestige & 378 & Prestige & 378 \\
\hline 0 & $1.6 \mathrm{aA}$ & $1.6 \mathrm{aA}$ & $1.8 \mathrm{aB}$ & $1.6 \mathrm{bA}$ & $1.8 \mathrm{aB}$ & $1.6 \mathrm{aA}$ \\
\hline 24 & $1.7 \mathrm{aA}$ & $1.5 \mathrm{bA}$ & $1.8 \mathrm{aA}$ & $1.6 \mathrm{bA}$ & $1.7 \mathrm{aA}$ & $1.8 \mathrm{aB}$ \\
\hline 49 & $1.8 \mathrm{aA}$ & $1.5 \mathrm{bA}$ & $1.8 \mathrm{aA}$ & $1.7 \mathrm{aAB}$ & $1.9 \mathrm{aA}$ & $1.8 \mathrm{aB}$ \\
\hline 98 & $1.8 \mathrm{aA}$ & $1.6 \mathrm{bA}$ & $1.8 \mathrm{aA}$ & $1.5 \mathrm{bA}$ & $1.9 \mathrm{aA}$ & $1.6 \mathrm{bA}$ \\
\hline 195 & $1.7 \mathrm{aA}$ & $1.5 \mathrm{aA}$ & $1.8 \mathrm{aA}$ & $1.4 \mathrm{bA}$ & $1.9 \mathrm{aA}$ & $1.5 \mathrm{bA}$ \\
\hline
\end{tabular}

Means within the same nitrogen level (row) and in the same mowing height followed by the same lowercase letter are not significantly different $(P>0.05)$. Means within the same buffalograss cultivar and in the same nitrogen level followed by the same uppercase letter are not significantly different $(P>0.05)$.

${ }^{a} \mathrm{~kg} \mathrm{~N} \mathrm{ha}^{-1} \mathrm{yr}^{-1}$.

${ }^{b}$ Standard error $=0.1$.

tivars, mowing height, and nitrogen treatments $(F=$ 2.32; df $=8,120 ; P<0.0237)$. The mean number of spiders was significantly greater in Prestige than 378 at all three mowing heights and in at least two nitrogen levels (Table 7).

Mowing Height and Nitrogen Effects. Pitfall Traps. Significant differences in the mean number of spiders among the three mowing heights in 378 were observed at 24 and $49 \mathrm{~kg} \mathrm{~N} \mathrm{ha}^{-1}$, but not at 0,98 , and $195 \mathrm{~kg} \mathrm{~N}$ $\mathrm{ha}^{-1}$ (Table 7). Significant differences in the mean number of spiders among the three mowing heights in Prestige were observed at the lowest nitrogen level $\left(0 \mathrm{~kg} \mathrm{~N} \mathrm{ha}{ }^{-1}\right)$, but not at $24,49,98$, and $195 \mathrm{~kg} \mathrm{~N} \mathrm{ha}^{-1}$ (Table 7).

\section{Ants}

Vacuum samples and pitfall traps collected 7,742 and 208,862 ants, respectively. Ants were the most abundant insect collected in this study, which is consistent with the statement of Potter (1998) that ants are the most abundant arthropod inhabitant of turfgrasses. Ants prey on the eggs and larvae of common insect pests, including white grubs and sod webworms (Potter 1998).

Buffalograss Cultivar Effects. Vacuum Samples. There was a significant interaction among buffalograss cultivars, collection dates, and mowing height treatments for both vacuum samples and pitfall traps $(F=1.73$; $\mathrm{df}=20$, 1,499; $P<0.0229)$. The mean number of ants collected in vacuum samples was generally more variable in 378 than in Prestige (Table 8 ). This variability likely resulted when randomly taken vacuum samples were collected over an ant mound or trail, and a disproportionate number of ants were collected.

Significant differences in the mean number of ants collected in the two buffalograss cultivars were observed (Table 8). Ants were more abundant in 378 than Prestige at the $5.0-\mathrm{cm}$ mowing height on collection dates $1,2,3,5,6,7$, and 10 (Table 8). Significant differences in the mean number of ants at the 2.5- and 7.5-cm mowing height occurred on collection dates 6 , 10 , and 11 and on dates 10 and 11 , respectively. 
Table 8. Mean number of ants collected in vacuum samples from two buffalograss cultivars among three mowing heights over 11 collection dates

\begin{tabular}{|c|c|c|c|c|c|c|}
\hline \multirow{3}{*}{ Date } & \multicolumn{6}{|c|}{ Mowing ht } \\
\hline & \multicolumn{2}{|c|}{$2.5 \mathrm{~cm}^{a}$} & \multicolumn{2}{|c|}{$5.0 \mathrm{~cm}^{a}$} & \multicolumn{2}{|c|}{$7.5 \mathrm{~cm}^{a}$} \\
\hline & Prestige & 378 & Prestige & 378 & Prestige & 378 \\
\hline 1 & $0.7 \mathrm{aA}$ & $0.7 \mathrm{aA}$ & $0.6 \mathrm{aA}$ & $1.0 \mathrm{bB}$ & $0.9 \mathrm{aA}$ & $0.7 \mathrm{aA}$ \\
\hline 2 & $0.7 \mathrm{aA}$ & $0.5 \mathrm{aA}$ & $0.5 \mathrm{aA}$ & $0.9 \mathrm{bB}$ & $0.5 \mathrm{aA}$ & $0.6 \mathrm{aAB}$ \\
\hline 3 & $1.0 \mathrm{aA}$ & $1.0 \mathrm{aA}$ & $0.9 \mathrm{aA}$ & $1.4 \mathrm{bB}$ & $0.9 \mathrm{aA}$ & $1.1 \mathrm{aAB}$ \\
\hline 4 & $0.5 \mathrm{aA}$ & $0.6 \mathrm{aA}$ & $0.9 \mathrm{aB}$ & $0.8 \mathrm{aAB}$ & $1.0 \mathrm{aB}$ & $1.0 \mathrm{aB}$ \\
\hline 5 & $0.9 \mathrm{aA}$ & $1.1 \mathrm{aA}$ & $0.9 \mathrm{aA}$ & $1.5 \mathrm{bB}$ & $1.1 \mathrm{aA}$ & $1.3 \mathrm{aAB}$ \\
\hline 6 & $0.5 \mathrm{aA}$ & $1.1 \mathrm{bA}$ & $0.7 \mathrm{aAB}$ & $1.2 \mathrm{bA}$ & $0.8 \mathrm{aB}$ & $1.0 \mathrm{aA}$ \\
\hline 7 & $0.6 \mathrm{aA}$ & $0.8 \mathrm{aA}$ & $0.8 \mathrm{aAB}$ & $1.2 \mathrm{bB}$ & $0.9 \mathrm{aB}$ & $0.9 \mathrm{aA}$ \\
\hline 8 & $0.5 \mathrm{aA}$ & $0.5 \mathrm{aA}$ & $0.4 \mathrm{aA}$ & $0.6 \mathrm{aA}$ & $0.6 \mathrm{aA}$ & $0.6 \mathrm{aA}$ \\
\hline 9 & $0.4 \mathrm{aA}$ & $0.5 \mathrm{aA}$ & $0.3 \mathrm{aA}$ & $0.4 \mathrm{aA}$ & $0.4 \mathrm{aA}$ & $0.5 \mathrm{aA}$ \\
\hline 10 & $0.3 \mathrm{aA}$ & $0.7 \mathrm{bA}$ & $0.4 \mathrm{aA}$ & $0.8 \mathrm{bA}$ & $0.3 \mathrm{aA}$ & $0.8 \mathrm{bA}$ \\
\hline 11 & $0.0 \mathrm{aA}$ & $0.5 \mathrm{bA}$ & $0.1 \mathrm{aA}$ & $0.5 \mathrm{aA}$ & $0.1 \mathrm{aA}$ & $0.6 \mathrm{bA}$ \\
\hline
\end{tabular}

Means in the same sampling date (row) and in the same mowing height followed by the same lowercase letter are not significantly different $(P>0.05)$. Means in the same sampling date (row) and in the same buffalograss cultivar followed by the same uppercase letter are not significantly different $(P>0.05)$.

${ }^{a}$ Standard error $=0.1$.

Pitfall Traps. There was a significant interaction among buffalograss cultivars, collection dates, and mowing height treatments $(F=2.80$; df $=20,1,498$; $P<0.0001)$. Although the general pattern of ant abundance was similar for both buffalograss selections, the effect of mowing height was more pronounced for Prestige, especially at the $2.5-\mathrm{cm}$ mowing height ( $\mathrm{Ta}$ ble 9 ). The mean number of ants was significantly greater in Prestige than 378 at the $2.5-\mathrm{cm}$ mowing height on all collection dates, except collection dates 9, 10, and 11. Significant differences in ant abundance at the $7.5-\mathrm{cm}$ mowing height were observed only on collection date 2 (Table 9).

Mowing Height Effects. Vacuum Samples. Significant differences in the mean number of ants collected at the three mowing heights were observed in both

Table 9. Mean number of ants collected in pitfall traps from two buffalograss cultivars among three mowing heights over 11 collection dates

\begin{tabular}{|c|c|c|c|c|c|c|}
\hline \multirow{3}{*}{ Date } & \multicolumn{6}{|c|}{ Mowing ht } \\
\hline & \multicolumn{2}{|c|}{$2.5 \mathrm{~cm}^{a}$} & \multicolumn{2}{|c|}{$5.0 \mathrm{~cm}^{a}$} & \multicolumn{2}{|c|}{$7.5 \mathrm{~cm}^{a}$} \\
\hline & Prestige & 378 & Prestige & 378 & Prestige & 378 \\
\hline 1 & $3.9 \mathrm{aA}$ & $3.2 \mathrm{bA}$ & $3.2 \mathrm{aB}$ & $3.4 \mathrm{aA}$ & $3.2 \mathrm{aB}$ & $2.9 \mathrm{aA}$ \\
\hline 2 & $4.8 \mathrm{aA}$ & $4.0 \mathrm{bA}$ & $3.7 \mathrm{aB}$ & $4.2 \mathrm{aA}$ & $4.2 \mathrm{aB}$ & $3.5 \mathrm{bB}$ \\
\hline 3 & 4.3aA & $3.7 \mathrm{bA}$ & $3.7 \mathrm{aB}$ & $4.0 \mathrm{aA}$ & $3.8 \mathrm{aAB}$ & $3.3 \mathrm{aA}$ \\
\hline 4 & $4.2 \mathrm{aA}$ & $3.2 \mathrm{bA}$ & $3.6 \mathrm{aB}$ & 3.6aA & $3.5 \mathrm{aB}$ & $3.0 \mathrm{aA}$ \\
\hline 5 & $4.4 \mathrm{aA}$ & 3.3bA & $3.5 \mathrm{aB}$ & $3.3 \mathrm{aA}$ & $3.3 \mathrm{aB}$ & $3.2 \mathrm{aA}$ \\
\hline 6 & $4.0 \mathrm{aA}$ & $3.0 \mathrm{bA}$ & $3.2 \mathrm{aB}$ & $3.0 \mathrm{aA}$ & $3.0 \mathrm{aB}$ & $2.9 \mathrm{aA}$ \\
\hline 7 & $3.8 \mathrm{aA}$ & $3.0 \mathrm{bA}$ & $3.1 \mathrm{aB}$ & $2.6 \mathrm{aA}$ & $2.9 \mathrm{aB}$ & $2.6 \mathrm{aA}$ \\
\hline 8 & $3.3 \mathrm{aA}$ & $2.5 \mathrm{bA}$ & $2.6 \mathrm{aB}$ & $2.1 \mathrm{aA}$ & $2.5 \mathrm{aB}$ & $2.1 \mathrm{aA}$ \\
\hline 9 & $2.3 \mathrm{aA}$ & $1.9 \mathrm{aA}$ & $2.1 \mathrm{aA}$ & $1.7 \mathrm{aA}$ & $1.9 \mathrm{aA}$ & $1.9 \mathrm{aA}$ \\
\hline 10 & $1.8 \mathrm{aA}$ & $1.6 \mathrm{aA}$ & $1.7 \mathrm{aA}$ & $1.5 \mathrm{aA}$ & $1.4 \mathrm{aA}$ & $1.4 \mathrm{aA}$ \\
\hline 11 & $1.4 \mathrm{aA}$ & $1.8 \mathrm{aA}$ & $1.5 \mathrm{aA}$ & $1.5 \mathrm{aA}$ & $1.4 \mathrm{aA}$ & $1.6 \mathrm{aA}$ \\
\hline
\end{tabular}

Means in the same sampling date (row) and in the same mowing height followed by the same lowercase letter are not significantly different $(P>0.05)$. Means in the same sampling date (row) and in the same buffalograss cultivar followed by the same uppercase letter are not significantly different $(P>0.05)$.

${ }^{a}$ Standard error $=0.6$
Table 10. Mean number of ants collected in vacuum samples from three mowing heights and five nitrogen levels

\begin{tabular}{rlll}
\hline \hline $\begin{array}{c}\text { Nitrogen } \\
\text { level }\end{array}$ & \multicolumn{3}{c}{ Mowing ht } \\
\cline { 2 - 4 } & $2.5 \mathrm{~cm}^{b}$ & $5.0 \mathrm{~cm}^{b}$ & $7.5 \mathrm{~cm}^{b}$ \\
\hline 0 & $0.55 \mathrm{aA}$ & $0.66 \mathrm{aB}$ & $0.73 \mathrm{aB}$ \\
24 & $0.72 \mathrm{bA}$ & $0.71 \mathrm{aA}$ & $0.69 \mathrm{aA}$ \\
49 & $0.64 \mathrm{abA}$ & $0.88 \mathrm{bB}$ & $0.66 \mathrm{aA}$ \\
98 & $0.60 \mathrm{abA}$ & $0.79 \mathrm{abB}$ & $0.68 \mathrm{aAB}$ \\
195 & $0.74 \mathrm{bA}$ & $0.74 \mathrm{abA}$ & $0.97 \mathrm{bB}$ \\
\hline
\end{tabular}

Means in the same mowing height (column) followed by the same lowercase letter are not significantly different $(P>0.05)$. Means in the same nitrogen level (row) followed by the same uppercase letter are not significantly different $(P>0.05)$.

${ }^{a} \mathrm{~kg} \mathrm{~N} \mathrm{ha}^{-1} \mathrm{yr}^{-1}$.

${ }^{b}$ Standard error $=0.1$.

buffalograss cultivars. Differences in the mean number of ants among the three mowing heights were not sufficient to clearly demonstrate higher numbers of ants at either the low or high mowing height (Table 8).

Pitfall Traps. The mean number of ants was generally greater at the lowest $(2.5-\mathrm{cm})$ mowing height, especially in Prestige. Significant differences in the abundance of ants collected in 378 were only observed on collection date 2 . Ant abundance was significantly greater at the 2.5-cm mowing height in Prestige at all collection dates, except dates 9, 10, and 11 (Table 9).

Nitrogen Effects. Vacuum Samples. There was a significant interaction among mowing height and nitrogen treatments $(F=2.77 ; \mathrm{df}=8,120 ; P<0.0075)$. This interaction likely occurred because the abundance of ants at the $5.0-\mathrm{cm}$ mowing height increased at $49 \mathrm{~kg} \mathrm{~N}$ $\mathrm{ha}^{-1}$, whereas the mean number of ants in both the 2.5- and 7.5-cm mowing height at the same nitrogen level were relatively the same (Table 10). The mean number of ants was significantly greater at the $195 \mathrm{~kg}$ $\mathrm{N} \mathrm{ha}{ }^{-1}$ at the $7.5-\mathrm{cm}$ mowing height than at the 0,24 , 49 , or $95 \mathrm{~kg} \mathrm{~N} \mathrm{ha}^{-1}$ treatments (Table 10). The greatest number of ants collected at the $5.0-$ and $7.5-\mathrm{cm}$ mowing heights occurred at 49 and $195 \mathrm{~kg} \mathrm{~N} \mathrm{ha}^{-1}$, respectively (Table 10). Differences in the mean number of ants across five nitrogen levels were not sufficient to clearly establish the presence of higher numbers of ants at either low or high nitrogen levels (Table 10).

Pitfall Traps. There was a significant interaction between mowing height and nitrogen treatments $(F=$ 2.32; $\mathrm{df}=8,120 ; P<0.0237)$. Differences in the mean number of ants collected among the three mowing heights were more pronounced at $49 \mathrm{~kg} \mathrm{~N} \mathrm{ha}^{-1}$ than at $0 \mathrm{~kg} \mathrm{~N} \mathrm{ha}{ }^{-1}$ (Table 11). In addition, there was a decrease in the abundance of ants at the 5.0- and 7.5-cm mowing height at $0 \mathrm{~kg} \mathrm{~N} \mathrm{ha}^{-1}$, whereas an increase in the mean number of ants occurred at the same nitrogen level at the 2.5-cm mowing height.

The mean number of ants was highest across all mowing heights in the $195 \mathrm{~kg} \mathrm{~N} \mathrm{ha}^{-1}$ plots (Table 11). The mean number of ants was significantly different in all mowing heights among the five nitrogen levels, except at the 5.0-cm mowing height (Table 11). 
Table 11. Mean number of ants collected in pitfall traps from three mowing heights and five nitrogen levels

\begin{tabular}{rlcl}
\hline \hline $\begin{array}{c}\text { Nitrogen } \\
\text { level }\end{array}$ & \multicolumn{3}{c}{ Mowing ht } \\
\cline { 2 - 4 } & $2.5 \mathrm{~cm}^{b}$ & $5.0 \mathrm{~cm}^{b}$ & $7.5 \mathrm{~cm}^{b}$ \\
\hline 0 & $3.0 \mathrm{aA}$ & $2.8 \mathrm{aA}$ & $2.8 \mathrm{abA}$ \\
24 & $3.1 \mathrm{abA}$ & $2.7 \mathrm{aB}$ & $2.4 \mathrm{aB}$ \\
49 & $3.1 \mathrm{abA}$ & $2.9 \mathrm{aA}$ & $2.4 \mathrm{aB}$ \\
98 & $3.3 \mathrm{bA}$ & $2.9 \mathrm{aB}$ & $2.7 \mathrm{aB}$ \\
195 & $3.4 \mathrm{bA}$ & $3.0 \mathrm{aB}$ & $3.2 \mathrm{bAB}$ \\
\hline
\end{tabular}

Means in the same mowing height (column) followed by the same lowercase letter are not significantly different $(P>0.05)$. Means in the same nitrogen level (row) followed by the same uppercase letter are not significantly different $(P>0.05)$.

${ }^{a} \mathrm{~kg} \mathrm{~N} \mathrm{ha}^{-1} \mathrm{yr}^{-1}$

${ }^{b}$ Standard error $=0.5$.

\section{Parasitoids}

The most abundant families of parasitioid Hymenoptera collected with sticky traps during the $2 \mathrm{yr}$ sampled were Aphelinidae (4,152), Braconidae (3,501), Trichogrammatidae (2,586), Mymaridae (6,348), and Scelionidae $(32,665)$. Scelionid wasps represented $66.3 \%$ of the total parasitoids collected. Interestingly, the scelionid wasp, Eumicrosoma benefica Gahan, is known to parasitize the eggs of lygaeid bugs in the genus Blissus (McColloch and Yuasa 1914, Dicke 1937, Reinert 1972, Wright and Danielson 1992). Because of this relationship, scelionid wasps were analyzed separately, and the information is presented below. All other parasitoid families were reported and analyzed as a single taxon.

Buffalograss Cultivar Effects. Sticky Traps. There was a significant interaction between buffalograss cultivars and collection dates $(F=3.89 ; \mathrm{df}=10,1,495 ; P<$ $0.0001)$. Significant differences in the mean number of scelionid wasps were observed during sampling dates 2,6, and 7 (Fig. 5). Although this study did not record the numbers of western chinch bug eggs, Baxendale et al. (1999) reported that western chinch bug eggs are laid during mid- to late May (first generation), and again in July (second generation). This corresponds to collections of higher numbers of scelionid wasps. These results suggest that the scelionid wasps collected in this study may be an important parasitoid of B. occiduus.

Mowing Height and Nitrogen Effects. Sticky Traps. The main effects of mowing height $(F=2.83$; $\mathrm{df}=2$, $20 ; P<0.0825)$ and nitrogen $(F=0.10 ; \mathrm{df}=4,120 ; P<$ 0.9814 ) were not significant. The total number of scelionid wasps collected among the three mowing heights and five nitrogen levels were approximately equal. These results suggest that neither mowing height nor nitrogen level has an important influence on the abundance of scelionid wasps. In contrast, higher mowing heights and nitrogen levels resulted in a trend toward higher numbers of western chinch bugs. This suggests that managing buffalograss at the lower mowing heights and reduced nitrogen rates may suppress western chinch bug infestations without adversely affecting scelionid abundance.

\section{Other Parasitoid Families}

Buffalograss Cultivar Effects. Sticky Traps. The main effect of buffalograss selection was also not significant $(F=2.31 ; \mathrm{df}=1,5 ; P<0.1888)$, suggesting that buffalograss cultivar has little influence on the abundance of parasitoid wasps. In contrast, more western chinch bugs were collected in 378 . This suggests that planting B. occiduus-resistant buffalograsses may suppress western chinch bug infestations without influencing parasitoid abundance.

Mowing Height and Nitrogen Effects. Sticky Traps. The main effect of mowing height was significant $(F=$ $7.98 ; \mathrm{df}=2,20 ; P<0.0028)$. The mean number of hymenopterous wasps collected in the 2.5-, 5.0-, and $7.5-\mathrm{cm}$ mowing heights were $1.9 \pm 0.1,2.0 \pm 0.1$, and $2.1 \pm 0.1$, respectively. Significant differences in the mean number of hymenopterous wasps were observed between the 2.5- and 5.0-cm mowing heights

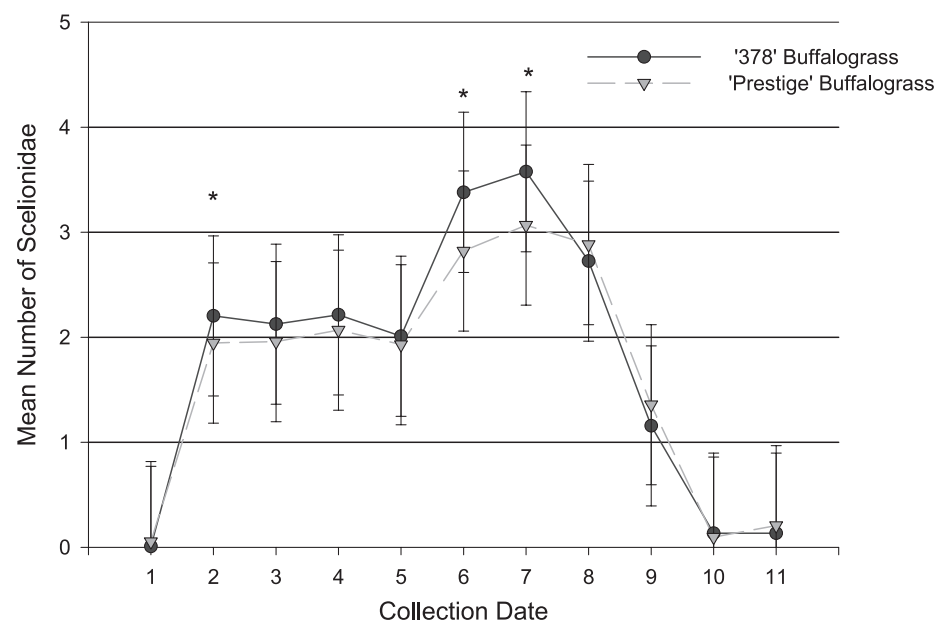

Fig. 5. Mean number of scelionid wasps collected with sticky traps from two buffalograss cultivars. *, significantly different at $P \leq 0.05$. 
and also between the 5.0- and 7.5-cm mowing heights. These differences were small $(<0.1$ wasp per sample) and are most likely not biologically significant. The main effect of nitrogen was not significant $(F=0.96$; $\mathrm{df}=4,120 ; P<0.4345)$, suggesting that neither mowing height nor nitrogen level has an important influence on the abundance of parasitoid wasps. Higher mowing heights and nitrogen levels, however, resulted in greater numbers of western chinch bugs. Managing buffalograss at the lowest mowing height with reduced nitrogen rates may suppress western chinch bug infestations without strongly influencing parasitoid abundance.

In conclusion, pitfall traps collected greater numbers of arthropods than vacuum samples, probably because of the longer collection period. Interestingly, for both mowing height and nitrogen level, the total number of western chinch bugs captured in vacuum samples closely reflected (although $\approx 75 \%$ fewer in numbers) those collected in pitfall traps. However, certain beneficial arthropods (e.g., rove beetles, ground beetles, and spiders) were rarely collected in vacuum samples, probably because of their evasive behavior, larger size, or both.

This research supports the findings of other researchers that buffalograss management practices do not strongly impact the abundance of B. occiduus. However, western chinch bugs were least abundant at the lowest mowing height $(2.5 \mathrm{~cm})$ and lowest nitrogen level $\left(0 \mathrm{~kg} \mathrm{~N} \mathrm{ha}^{-1}\right)$. Higher mowing heights may provide more favorable environmental conditions, protection from predators, and be preferred due to greater amounts of organic debris. Higher nitrogen levels may provide the buffalograss with greater nutritional value, thereby increasing fecundity, reducing egg and nymphal mortality, increasing survivorship, and reducing developmental times.

This research also supports the findings of HengMoss et al. (2002) that Prestige is a nonpreferred host of B. occiduus. Use of this buffalograss may help suppress outbreaks of B. occiduus and its associated damage.

This research also concurs with the findings of Heng-Moss et al. (1998), who concluded that the abundance of beneficial arthropods in buffalograss is not strongly affected by turfgrass management practices. Numbers of beneficial arthropods at the various mowing heights and nitrogen levels were statistically significant in many cases; however, these differences were small and their biological meaning remains unclear. This study provides the first comprehensive overview of the influence of buffalograss management practices on B. occiduus and its beneficial arthropods.

In their nitrogen effects/mowing height study, Frank et al. (2004) concluded that for the cultivars tested, $98 \mathrm{~kg} \mathrm{~N} \mathrm{ha}{ }^{-1}$ or greater maintained or improved buffalograss quality, whereas lower rates of nitrogen resulted in reduced turf quality. Mowing heights of 5.0- to $7.5-\mathrm{cm}$ were optimum for all buffalograsses, but Prestige and 378 preformed best under a 2.5-cm mowing height regime. This study suggests that lower to intermediate nitrogen rates $(98 \mathrm{~kg} \mathrm{~N}$ $\mathrm{ha}^{-1}$ ) and mowing heights $(2.5$ to $5.0 \mathrm{~cm}$ ), although providing acceptable buffalograss performance, may serve to suppress B. occiduus numbers and leave most beneficial arthropods intact.

\section{Acknowledgments}

We thank Tom Eickhoff, Jessica Hurd, and Robert Roselle for technical assistance. We gratefully acknowledge Robert Wright and Terrance Riordan for reviewing this manuscript. This research was supported in part by the University of Nebraska Agriculture Experiment Station Projects 17-062. This is paper number 15226 of the journal series of the Agricultural Research Division, University of Nebraska-Lincoln.

\section{References Cited}

Baxendale, F. P., J. M. Johnson-Cicalese, and T. P. Riordan. 1994. Tridicus sporoboli and Trionymus sp. (Homoptera: Pseudococcidae): potential new mealybug pests of buffalograss turf. J. Kans. Entomol. Soc. 67: 169-172.

Baxendale, F. P. 1997. Insects and related pests of turfgrass, pp. 32-78. In F. P. Baxendale and R. E. Gaussoin [eds.], Integrated turfgrass management for the Northern Great Plains. Coop. Ext., University of Nebraska-Lincoln. EC971557.

Baxendale, F. P., T. M. Heng-Moss, and T. P. Riordan. 1999. Blissus occiduus (Hemiptera: Lygaeidae): a chinch bug pest new to buffalograss turf. J. Econ. Entomol. 92: 169172.

Beard, J. B. 1973. Turfgrass: science and culture. PrenticeHall, Englewood Cliffs, NJ.

Bird, R. D., and A. V. Mitchener. 1950. Insects of the season 1949 in Manitoba. Can. Insect Pest Rev. 28: 41.

Borror, D. J., C. A. Triplehorn, and N. F. Johnson. 1989. An introduction to the study of insects, 6th ed. Saunders College Publishing, Philadelphia, PA.

Braman, S. K., and A. F. Pendley. 1993. Relative and seasonal abundance of beneficial arthropods in centipedegrass as influenced by management practices. J. Econ. Entomol. 86: 494-504.

Busey, P., and G. H. Snyder. 1993. Population outbreak of the southern chinch bug is regulated by fertilization. Int. Turfgrass Soc. Res. J. 7: 353-357.

Cockfield, S. D., and D. A. Potter. 1985. Predatory arthropods in high and low maintenance turfgrass. Can. Entomol. 117: 423-429.

Dicke, F. F. 1937. Eumicrosoma benefica Gahan as an egg parasite of the hairy chinch bug. J. Econ. Entomol. 30: 376.

Frank, K. W., R. E. Gaussoin, T. P. Riordan, R. C. Shearman, J. D. Fry, E. D. Miltner, and P. G. Johnson. 2004. Nitrogen rate and mowing height effects on turf-type buffalograss. Crop Sci. 44: 1615-1621.

Heng-Moss, T. M., F. P. Baxendale, and T. P. Riordan. 1998. Beneficial arthropods associated with buffalograss. J. Econ. Entomol. 91: 1167-1172.

Heng-Moss, T. M., F. P. Baxendale, T. P. Riordan, and J. E. Foster. 2002. Evaluation of buffalograss germplasm for resistance to Blissus occiduus. J. Econ. Entomol. 95: 10541058.

Heng-Moss, T. M., F. P. Baxendale, T. P. Riordan, L. J. Young, and K. W. Lee. 2003. Chinch bug-resistant buffalograss: an investigation of tolerance, antixenosis, and antibiosis. J. Econ. Entomol. 96: 1942-1951. 
Horn, G. C. 1962. Chinch bugs and fertilizer, is there a relationship? Fla. Turf-Grass Assoc. Bull. 9: 3-5.

Kerr, S. H. 1966. Biology of the lawn chinch bug, Blissus insularis. Fla. Entomol. 49: 10-18.

Kortier Davis, M. G., and D. R. Smitley. 1990. Relationship of hairy chinch bug (Hemiptera: Lygaeidae) presence and abundance to parameters of the turf environment. J. Econ. Entomol. 86: 2375-2379.

McColloch, J. W., and H. Yuasa. 1914. A parasite of the chinch bug egg. J. Econ. Entomol. 7: 219-27.

Morrill, W. L. 1975. Plastic pitfall trap. Environ. Entomol. 4: 596.

Potter, D. A. 1998. Destructive turfgrass insects biology, diagnosis, and control. Sleeping Bear Press, Chelsea, MI.

Reinert, J. A. 1972. Distribution and host record for the parasitoid Eumicrosoma benefica. Fla. Entomol. 55: 143144.
Riordan, T. P., F. P. Baxendale, R. E. Gaussoin, and J. E. Watkins. 1998. Buffalograss: an alternative native grass for turf. Nebr. Coop. Ext. G96-1297-A.

SAS Institute. 1999. SAS/STAT software: changes and enhancements through release 8.2. SAS Institute, Cary, NC.

Slater, J. A. 1964. A catalogue of the Lygaeidae of the world. University of Connecticut, Storrs, CT.

Vittum, P. J., M. G. Villani, and H. Tashiro. 1999. Turfgrass insects of the United States and Canada, 2nd ed. Cornell University Press, Ithaca, NY.

Wright, R. J., and S. D. Danielson. 1992. First report of the chinch bug (Heteroptera: Lygaeidae) egg parasitoid Eumicrosoma beneficum Gahan (Hymenoptera: Scelionidae) in Nebraska. J. Kans. Entomol. Soc. 65: 346-348.

Received 19 June 2006; accepted 28 October 2006. 